Ritrýnd grein birt 31. desember 2020

\title{
"This is the first time as a foreigner that I have had such a strong connection to the state": Parents' voices on Icelandic school staying open in the time of COVID-19
}

\author{
Elizabeth B. Lay and Brynja E. Halldórsdóttir \\ Abstract \\ Um höfunda \\ About the authors \\ Heimildir
}

Iceland is one of a handful of countries that elected to keep their preschools and compulsory schools at least partially open throughout the first wave of the COVID-19 pandemic. By doing so, Icelandic officials sought to maintain a sense of routine for children and minimize the social and economic complications now threatening other nations after months of school closures. This study explores how parents responded to the government strategy of continuing children's schooling in a time of crisis. We aim to understand parents' perspectives based on their levels of trust and the strength of their information and social network by asking how they accessed and interpreted information from Icelandic authorities during this time. Using social capital theory, we examine parents' confidence in the government response strategy, their connectedness to Icelandic societal norms, and their social and economic concerns due to an unprecedented global crisis. We conducted an online survey in May 2020, with closed-ended and open-ended questions targeting Icelandic and immigrant parents, yielding 356 completed responses and accounting for 569 preschool and compulsory-age children. Most respondents were female and well-educated, and about half were native Icelandic and half were with an immigrant background. Findings indicate that the majority of the Icelandic and immigrant parents who responded were optimistic and trusted the schools' and authorities' recommendations. While few parents felt the burden of further exposing their children to infection, there was a strong societal pressure to follow social norms and behavior as recommended by the Icelandic authorities and keep children in school. This study contributes to our understanding of the significance of parental social networks for civic engagement in the time of COVID-19.

Keywords: COVID-19 in Iceland, public trust, school operations, parents, social capital, social networks

\section{Introduction}

The COVID-19 pandemic will continue to have wide ranging impacts on the global community for the foreseeable future. Understanding societal responses to these changes can be a useful strategy for overcoming the crisis in which we now find ourselves. National responses to the pandemic have varied greatly. This holds for general societal and governmental responses as well as education system responses. Many societies reacted by closing schools and shutting down all but essential services (The virus that shut down the world, 2020). Iceland's response to the pandemic was a blend of mitigation measures and closures aimed at minimizing both the infection rates and the social and economic impact of COVID-19 (Price, 2020). Our study explores how parents in Iceland of preschool (ages 
"This is the first time as a foreigner that I have had such a strong connection to the state":

Parents' voices on Icelandic school staying open in the time of COVID-19

2-5) and compulsory school-aged children (ages 6-16) responded to the government strategy of keeping schools open during the first wave of the COVID-19 pandemic. Anecdotal evidence in the authors' parental and social media networks raised questions around parents' responses towards the pandemic response strategy. The discussions related especially to school openings and several media reports regarding immigrants (Holm, 2020; Johannessen, 2020), bringing our attention to potential differences among parents' responses. Such unusual societal conditions created an opportunity to look at how parents' understanding of and response to recommendations from Icelandic authorities relates to their sense of connectedness to Icelandic societal expectations and authorities.

In this mixed methods study, our aim was to better understand whether there were significant differences between immigrants' and native Icelandic parents' perspectives on and access to information during the first wave of the COVID-19 pandemic. Using social capital theory, we examined parents' confidence in authorities' response measures, their perceived connectedness to Icelandic societal norms, and their social and economic concerns. Research in social capital theory and institutional trust provided a framework for understanding how social groups may or may not differ in relation to trust in authorities to facilitate social collective action. An online survey in Icelandic and English with quantitative and qualitative strands was administered between mid-May and mid-June. Participants ( $\mathrm{n}=356$ ) were recruited through various social online media networks and snowball sampling. Social relationships, understood as bonding and bridging ties, enabled analysis of the relational connections within and across social groups (Bankston, 2014; Putnam, 1995, 2001). We hypothesized that parents exhibit greater trust in the system using both weak and strong ties to Icelandic society and culture, and thereby indicate more confidence in the Icelandic public response to COVID-19.

\section{Iceland's response to the first wave}

The dramatic spread of the COVID-19 pandemic forced governments around the world to initiate disease containment strategies, creating shifts in social norms, behavior, and conventions. To understand how these shifts progressed in Iceland, we must contextualize the development of the first wave of infections in the country. We focus particularly on how the country's uncommon response to school operations relates to parents' level of trust in the schools and the authorities.

In late February 2020, governments worldwide began to announce widespread lockdowns and temporary closures of schools and universities to mitigate the spread of the virus that causes COVID-19. Within a month, school interruptions had affected over 1.7 billion learners worldwide, or $60 \%$ of the world's enrolled learners (UNESCO, 2020a). The severe government sanctions were intended to repress the pandemic but will undoubtedly have major societal and economic implications yet to be determined. School closures and interrupted learning environments at this massive scale may be potentially harmful. It has also exposed how disadvantaged students are disproportionately affected, regarding childcare security, stress on parents for distance and homeschooling, increased exposure to violence and exploitation, social isolation, and high economic costs (Armitage \& Nellums, 2020; Doyle, 2020; UNESCO, 2020b).

The first confirmed case of COVID-19 in Iceland was reported on February 28, 2020, and cases in the following days seemed to originate from individuals returning from travel abroad (Jónsson, 2020). On March 6, the first two cases to have been contracted domestically were reported, bringing the total number of confirmed cases to 43. At this point, the Department of Civil Protection and Emergency Management (i. Almannavarnir) raised the national alert level to a state of emergency. Declaring a state of emergency allowed for institutions and companies to enact preventive restrictions. Mitigation measures were rolled out in stages, primarily restricting large gatherings and closing public venues and businesses. Daily televised news briefings on state television and radio also began on March 6, led by three main spokespersons, Chief Epidemiologist Pórólfur Guðnason, Director of Health Alma Möller, and Chief Superintendent Víðir Reynisson. The Ministry of Education instructed schools to prepare for some form of distance learning or extended support in case schools might be closed. 
However, school leaders emphasized that closing preschools especially would be complicated for families and students, taking into account closings that were already happening due to recent union strikes1 (Prastardóttir, 2020).

A national assembly ban went into effect on March 16 (see Figure 1). Gatherings were restricted to no more than 100 people, with a two-meter distance between individuals, excluding children aged 14 and under. Universities and upper-secondary schools 2 closed, and classes were moved completely online. Preschools and compulsory schools would be allowed to stay open with restrictions (Embætti landlæknis (Directorate of Health), 2020). At the same time, screening for the virus became available using certain criteria (Bjarnason, 2020). During their daily news briefings and interviews, the authorities reiterated the overwhelming risks of mandated curfew and closings, including school closings. When questioned by reporters about the leniency of the preventative measures in comparison to other countries, especially that of continuing school operations, the Chief Epidemiologist continued to defend the view that the best approach included early detection, isolating the infected, and quarantining those possibly infected (Árnason, 2020). As such, if an infection was confirmed in a school, the staff and students in proximity to the infected were also put in quarantine for two weeks. By March 19, three preschools and two compulsory schools had closed due to confirmed contamination ("Prír leikskólar og tveir grunnskólar lokaðir" 2020).

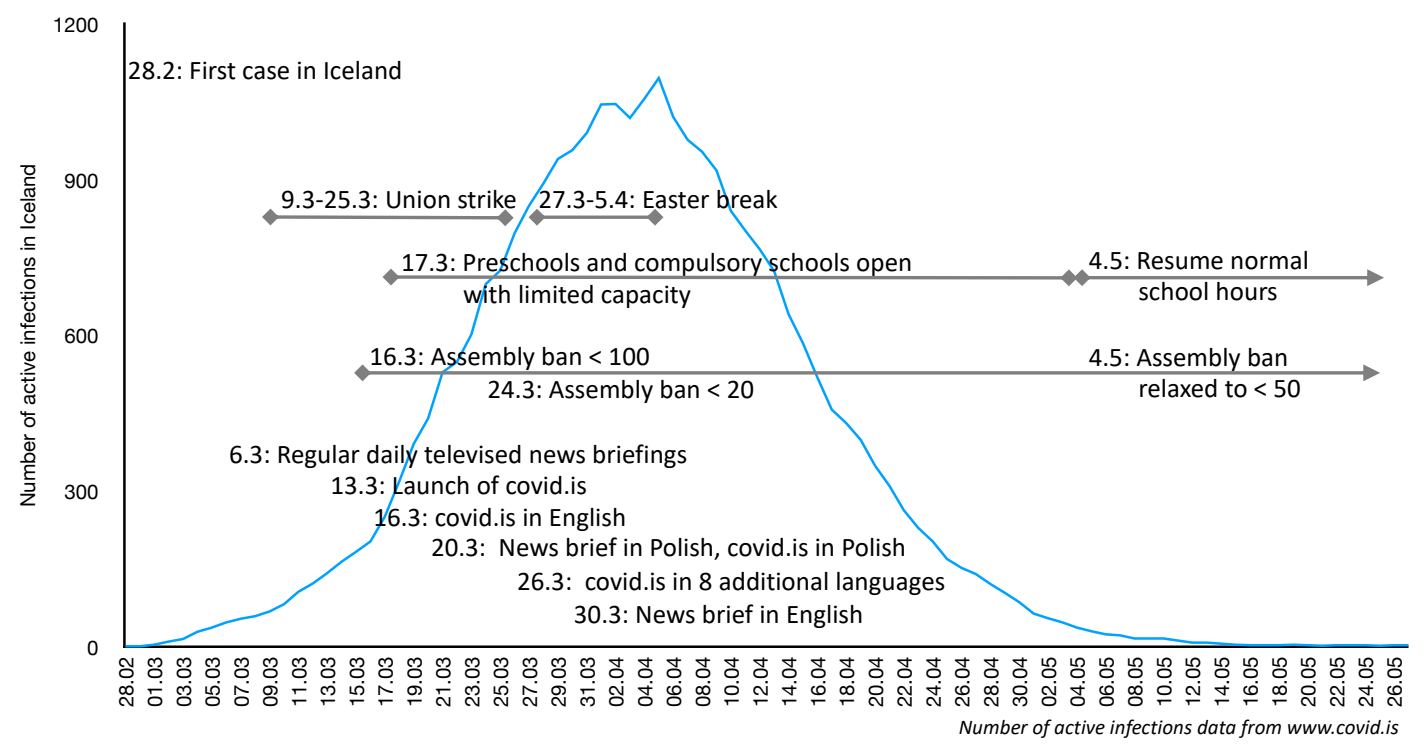

Figure 1. February to May 2020 timeline of active infections in Iceland, actions related to school openings, and communication of COVID-19 news.

Each school thus operated according to recommendations by the Directorate of Health (Embætti landlæknis, 2020) to restrict the number and proximity of students. Schools were allowed to continue if they could ensure no more than 20 students in a classroom with no group mixing. Preschools would try to keep small groups and keep mixing to a minimum. School spaces were cleaned and disinfected daily. The national guidelines recommended that healthy children continue to attend school, but each school was entrusted with executing those restrictions independently. The resulting schedules ranged from reduced hours of school per week to complete closings while the assembly ban was active (Magnússon, 2020). Classes and assignments for older grades could be transferred online. After-school care centers (i. frístundir), sport activities, school bands, and other group leisure activities were also revised to adhere to the restrictions. Moreover, other disruptions coincided with the restricted school schedule. The union strike that caused some schools to close for a few days and 
"This is the first time as a foreigner that I have had such a strong connection to the state":

Parents' voices on Icelandic school staying open in the time of COVID-19

the Easter holiday break both overlapped around the peak of the active infections (see Figure 1). Infection rates in Iceland started to rapidly increase in March 2020 and restrictions were further tightened on March 24.

By keeping schools open and providing a minimal sense of routine for children, Icelandic officials sought to avoid the challenges of unprecedented, adverse complications faced by other nations after months of school closures (Armitage \& Nellums, 2020; Burgess \& Sievertsen, 2020; Doyle, 2020). Slow mitigation measures and keeping schools open was in contrast with other countries who opted for more severe social isolation (Ortiz, 2020; UNESCO, 2020a, 2020b), a notable exception would be Sweden (Pearce et al., 2020). Instead, state-wide campaigns with slogans such as 'Civil defense is in our hands' (Embætti landlæknis og almannavarnadeild ríkislögreglustjóra (Directorate of Health \& Department of Civil Protection and Emergency Management), n.d.) were the subtle "moral nudges" intended to influence cooperative behavior (Capraro et al., 2019). On March 23, 2020, during one of the daily news briefings, the Chief Epidemiologist again reinforced the country's position on school operations, stating, "Based on these figures, we see no significant transmission among children. This debate about the high levels of infection and the threat of infection in schools is not apparent in these figures as of now" (Logadóttir, 2020; author's translation from Icelandic). Overall, the Icelandic response had been focused on the unification of the national response while at the same time relying on individual responsibilities.

In the same way that schools were trusted to manage their own response to the restrictions, individuals were also entrusted to regulate their own social distancing and preventative behavior. Studies are emerging regarding how parents in Iceland have responded to keeping schools open (Auðardóttir $\&$ Rúdólfsdóttir, 2020). Social media forums became a platform to assert warnings and questions, where parents expressed concerns about their children's safety, often citing resources from abroad (B. Halldórsdóttir \& E. Lay, personal communication in private Facebook groups, March 2020). News reports highlighted the economic impact and social isolation for vulnerable groups, including foreign-origin families (Holm, 2020; Ingvarsson, 2020). Another report highlighted the possibility that non-Icelandic speaking parents were less informed and had to rely on news and updates from abroad or wait until translations were available, a possible explanation for fewer children of foreign origin coming to school (Johannessen, 2020). Furthermore, the number of immigrants that tested positive for the virus was four percent in April, despite the total population of immigrants living in Iceland being about 14 percent. This created additional concern to engage immigrants and a special effort was made to encourage non-native Icelandic residents to register for testing (Ómarsdóttir, 2020).

Recent literature on the integration of immigrants in Iceland supports this concern, highlighting their lack of equal access opportunities (Einarsdóttir et al., 2018; Harðardóttir \& Magnúsdóttir, 2018; Wilson \& Aðalbjarnardóttir, 2019), not excluding their experiences in education. While research shows that interpersonal relationships are considered positive (Sævarsdóttir et al., 2013), the collaboration between schools and families of foreign origin in Iceland continues to be hindered by several factors, such as language and communication (Magnúsdóttir, 2010), limited parent participation or cooperation (Gunnpórsdóttir et al., 2019; Lay, 2016), and the challenging social and economic circumstances of immigrants (Runarsdottir \& Vilhjalmsson, 2015).

In order to reach non-Icelandic speaking residents regarding COVID-19 communiqués, news updates were gradually provided in other languages. A handful of outlets additionally provided public service announcement-style information and posters in multiple languages, notably from Red Cross Iceland and the City of Reykjavík. Part of the daily news briefing was delivered in Polish on March 20 and in English on March 30. The extensive website, www.covid.is, launched on March 13 and intended to be used as a primary source of pandemic information, was at first available in Icelandic only and provided news, guidelines, contact information and daily updates on infected cases. An English page followed on March 16, Polish on March 20, and multiple languages on March 26, although the content was often not as thorough as the Icelandic page. Considering the rapid spread of the virus 
worldwide, it would have been of vital importance to provide local updates to as many people as possible. While the website was translated into English three days after its Icelandic language launch, it came 17 days after the first infected case in Iceland. Otherwise, it is unknown how non-Icelandic speaking residents gathered their information during this period.

By April 5, the number of infected cases from the first wave reached its peak with 1,096 cases, steadily decreasing to 37 cases by May 4 (Embætti landlæknis og almannavarnadeild ríkislögreglustjóra, n.d.). The ban on gatherings was then relaxed and schools resumed normal hours. There was never a full lockdown nor nationwide closing of preschools and compulsory schools. Iceland remains one of very few countries that kept their preschools and compulsory schools at least partially open throughout the first wave of the COVID-19 pandemic. This difference in governmental response provides an opportunity to focus on parents' reactions towards the more "relaxed" mitigation measures.

\section{A social capital approach to trust}

At its core, the concept of social capital is based on connections. There is value in our social connections, from personal relationships to expansive social networks. According to Ostrom and Ahn (2009), the social capital approach sees "trust and norms of reciprocity, networks and forms of civic engagement, and both formal and informal institutions" as the "causes of behavior and collective social outcomes" (p. 18). Putnam (1993) has defined social capital in communities as the "features of social organizations, such as networks, norms and trust that facilitate coordination and cooperation for mutual benefit." (p. 35). He further describes social relationships as bonding ties and bridging ties, allowing for analysis of the relational connections within and across social groups (Bankston, 2014; Putnam, 1993, 2001) and particularly pertinent when researching diverse communities. As networks overlap and function with both bonding and bridging social capital, even small connections or acquaintances can increase social trust. Bonding ties, such as with close family and friends, tend to reflect durable connections within a definable group, with high degrees of trust and similarities in values and motivations (Larsen et al., 2004). They are part of the inner circle relationships that are immediately available and are helpful in protecting individuals from isolation, even fostering strategic bridging across networks. Conversely, bridging ties are commonly made across groups or outside of one's network, such as with work acquaintances. These are the relationships that are loosely connected and less risky, but possibly as important to access information or achieve a goal (Putnam, 1993), even creating opportunities for upward mobility (Granovetter, 1983; Lin, 2000).

Long before the terms "bonding" and "bridging" capital came to use, Granovetter (1973) likewise described the "strength of weak ties" as a means to access resources in social networks. Social networks are made of both strong (bonding) and weak (bridging) ties that can benefit individuals and communities in different ways. Lin (2008) describes these as layers of social relations differentiated by levels of reciprocity, where the strongest ties are characterized by shared sentiment and mutual support. There may also be an intermediary layer, where strong relationships exist but may not need direct interaction, a mixture of strong and weak ties that are still considered bonding. Finally, relationships based only on shared membership or identity (member of an organization, workplace), can create a sense of belonging even if there is no interaction among members. The usefulness of these relations depends on the intended goal of the action. The strength of weak ties can help procure a coveted job thanks to a few good contacts who are not in one's 'inner circle'. Thus, Lin refers to weak ties as social resources that can have more significant effects in mobilizing collective action that spans many networks.

Where bonding ties benefit individuals who are family, or share a nationality, they can also be found in other ways when people become more embedded in a network, such as living in a neighborhood or community for a long time (Larsen et al., 2004; Sampson, 1988). For immigrants and immigrant/ multicultural communities, it is considered advantageous to develop social networks as a source of social capital to increase socialization and social mobility. Ryan et al. (2008) found that migrants build complex bonding and bridging capital differently from non-migrants. However, bonding ties 
"This is the first time as a foreigner that I have had such a strong connection to the state":

Parents' voices on Icelandic school staying open in the time of COVID-19

alone can also be too strong, causing distrust towards wider networks and limiting collaboration, so not all immigrants necessarily need or want to socialize with co-ethnics (Ryan et al., 2008). Connections, then, are ultimately a means to an end, whether they are strong, weak, few or many. Returning to Putnam's $(1993,2001)$ definition of social capital, the civic engagement of a complex society is built on social assets of connections and trust.

In contemporary societies trust in social and public institutions and organizations is of vital importance. Research on institutional and social trust has a long history (e.g., Fukuyama, 2001; Knack, 2003; Kumlin \& Rothstein, 2010; Putnam, 2001). In this paper, we understand social and institutional trust as the expectation individuals have towards society, as well as their understanding and belief that institutions, such as schools, have people's best interests in mind (Nannestad, 2008). Research has shown that social trust appears closely linked to its production through institutions and governmental policy development (Delhey \& Newton, 2003; Dinesen, 2011; Knack, 2003). Nannestad st al. (2014) found that trust is either seen as a product of institutions and government policies or a cultural and societal development, thus causally connected to civic participation.

Recent research in Europe and the Nordic countries (Dinesen, 2011, 2013; Nannestad, 2008; Nannestad et al., 2014; Röder \& Mühlau, 2012) has shown that immigrant groups in these countries show higher social trust than their compatriots in their home countries. In their research on immigrant groups and institutional trust in Denmark, they argue that institutional trust impacts social trust, although it is not the only factor to impact social trust. While immigrants in Denmark still exhibit lower levels of trust than "local" Danish populations, their levels of trust in institutions are significantly higher than among those who are in their home countries, especially when it comes to institutions (Nannestad et al., 2014). Nannestad et. al (2014) further argue that good institutions lead to greater trust, as these can be depended upon and are considered to be "fair and just" in their dealings (p. 547). While no such comparative studies exist in the Icelandic context, we note that similarities exist between Iceland and other Nordic cultures with regard to social and institutional structure.

In the Icelandic context, trust towards public institutions has tended to be rather high outside of a brief low during the economic collapse and the subsequent economic recovery (Bjarnason, 2014). In the most recent Market and Media Research poll on trust, conducted during the COVID-19 epidemic, civil protection (91\%) (i. Almannavarnir) and health institutions (88\%) were considered highly trustworthy, while schools (62\%) were considered somewhat trustworthy (MMR, 2020b). We argue that schools, which are fundamental social and public institutions, are important sites of trust building (Delhey \& Newton, 2003; Fukuyama, 2001). In many cases schools are places where immigrants come into regular, direct contact with local cultures (Gunnpórsdóttir et al., 2019), and thus are important sites for communication and trust building.

In the past twenty years in Iceland, policies and strategic plans based on improving and responding to the growing immigrant populations have placed emphasis on developing a family-friendly society that promotes equity and the active participation of all individuals (Félagsmálaráðuneytið (Ministry of Social Affairs), 2007; Ríkisendurskoðun (National Audit Office), 2015; Pingsályktun nr. 63/145 (parliamentary bill in toto), 2015-2016; Pingsályktunartillaga nr. 38/150 (parliamentary resolution), 2019-2020). One aspect of this focus has been the discussion on school and parent collaboration (Karvelsdóttir \& Guðjónsdóttir, 2010; Ólafsdóttir et al., 2012; Sigurðardóttir, 2020). Research in Iceland has shown that parent-school collaboration is an ongoing concern with regard to immigrant parent participation, although research on the issue is only nascent (Gunnpórsdóttir et al., 2019; Lay, 2016; Sævarsdóttir et al., 2013; Samson, 2014).

If trust is an underlying indicator of a healthy society (Dinesen, 2013), and schools, as institutions, represent an important connection between the immigrant population as well as access to the host country's social network (Ryan et al., 2008), schools become an ideal environment to increase social cohesion and sites for building social capital. It becomes critical to understand how immigrants, as a 
growing population, are connected to this development through bonding or bridging ties, and how they contribute towards collective action. There has been some related research on social capital for collective action (Jóhannesson et al., 2003; Larsen et al., 2004) and social capital in pandemic responses (Pitas \& Ehmer, 2020; Wong \& Kohler, 2020). Considering Iceland's "We're all in this together" ethos and the urgency of information access in COVID times, social capital becomes a useful concept to understand how well-equipped Icelandic and immigrant parents are to respond to crisis situations. As such the article asks three primary research questions: What were Icelandic and immigrant parents' responses to the authorities' COVID-19 mitigation measures? What were Icelandic and immigrant parents' responses to the restricted school operations during the first wave of COVID-19? How do characterizations of bridging and bonding capital reflected in Icelandic and immigrant parents' responses relate to their general levels of trust?

\section{Methods}

This study documents parents' perspectives during the first wave of the pandemic in Iceland. As discussed above, the purpose was to understand the ways parents in Iceland responded to information from public authorities during unstable times. The study uses a convergent mixed methods design within one survey instrument that contained both closed-ended and open-ended questions (Moseholm $\&$ Fetters, 2017). In using mixed methods the researchers are able to, "synthesize complementary quantitative and qualitative results to develop a more complete understanding of a phenomenon, and comparing multiple levels within a system" (Creswell \& Plano Clark, 2011, p. 77). We argue that using both quantitative and qualitative measures allows for a broader and deeper data set, which in turn generates more nuanced analysis and discussion in response to the research questions.

\section{Study design and data analysis}

Due to the rapid development of the pandemic and general societal shut-down, an online survey was a viable, effective tool to reach a wide range of parent participants in Iceland in a short time. The survey included quantitative and qualitative strands, collecting information on: demographic details, accessibility to COVID-19 news and information, experiences related to school operations during COVID-19, and perceptions of how the pandemic was handled in Iceland (see Appendix). The quantitative strand comprised 13 questions from the 35-item survey, including information about the participants' gender, country of birth, languages spoken in the home, education attainment, work status, self-assessment of Icelandic fluency, and actions related to the pandemic and school operations. Additionally, Likert scale items were used to assess parents' levels of satisfaction and concern with school operations and COVID-19 in Iceland. Our survey included the option to report different experiences for each of the school aged children in the household. The survey was prepared in English and Icelandic using the online survey software Qualtrics.

The survey was first pilot tested by two Icelandic parents and three foreign-born parents. They completed the survey and provided feedback. The survey was then revised to clarify and refine the wording of the questions. The survey contained the required informed consent, and the confidentiality and anonymity of respondents were maintained. At the end of the survey, participants were offered the option of entering their names in a lottery to win one of five gift cards worth 10,000 kronur. The names collected for the lottery were separate from the survey itself. The survey was launched on May 10, 2020 and remained open until June 8,2020. We felt it was important to collect responses shortly after, but not during, the most stressful time of the first wave, so that parents could answer more accurately and reflect on their decisions.

The quantitative data were analyzed using SPSS and Microsoft Excel with a simple descriptivefrequency analysis. During the analysis we also conducted several correlation tests using a chi squared test for independence ( $\mathrm{p}<.1$ ) to assess the correlation of such aspects as level of education, self-assessed Icelandic language skills and country of origin with views on public authorities' and 
school level responses to the COVID-19 pandemic. To illuminate potential differences between those who reported being born in Iceland and those who were not, we conducted several chi-squared tests based on self-assessment of language skill. In this case, we distinguished between participants who were born in Iceland and reported language proficiency and those born outside of Iceland and reported language proficiency. We chose to focus on self-reporting of language proficiency rather than languages spoken at home because we felt that proficiency indicated the participants' confidence in their language skills. Furthermore, one of the focal points relating to immigrant integration into Icelandic society has been level of Icelandic language skills (Félagsmálaráðuneytið, 2007; Ríkisendurskoðun, 2015; Pingsályktun nr. 63/145, 2015-2016; Pingsályktunartillaga nr. 38/150, 2019-2020).

The qualitative strand comprised an open-ended question and answer format, allowing participants to provide answers expressing why they chose to keep their child at home or at school during significant points of the outbreak. These items were optional for respondents; in total 187 participants completed the qualitative sections (Table 1 ). The responses were analyzed using a thematic analysis framework (Braun \& Clarke, 2013) to derive common themes regarding parents' satisfaction or concerns with their decisions, such as: convenience, duty to protect, fear of virus, unafraid of virus, trust in authorities, and job commitment. After analyzing the quantitative and the qualitative strands independently, a second round of analysis was conducted to integrate the datasets, allowing us to build a more comprehensive picture of parent perspectives.

\section{Target population and participant characteristics}

The target population for this study was parents of preschool or compulsory school-age children in Icelandic schools during the first wave of the COVID-19 pandemic. Those who were over 18 years of age, and able to answer the questions in Icelandic or English were eligible to participate in the survey. The online survey was distributed via several active Facebook groups for international and Icelandic parents, combined with a snowball sampling technique where the researchers asked eligible persons to complete the survey and share it with other parents. The goal was to collect data quickly while the threat of COVID-19 was still imminent. The survey sample is non-random and not intended to represent the general opinions or actions of this group. The intention was to document and capture the experiences and concerns of parents from a range of sociodemographic backgrounds. 
Table 1. Characteristics of participants according to birth country (totals may vary due to missing data).

\begin{tabular}{lccc}
\hline & $\begin{array}{c}\text { Born in } \\
\text { Iceland } \mathbf{n} \mathbf{1 7 6}\end{array}$ & $\begin{array}{c}\text { Born Abroad } \\
\mathbf{n = 1 8 0}\end{array}$ & $\begin{array}{c}\text { Total } \\
\mathbf{\%}\end{array}$ \\
\hline Sociodemographic characteristics & 167 & 167 & $94 \%$ \\
$\quad$ Female & 59 & 38 & $27 \%$ \\
Education less than bachelor's degree & 51 & 45 & $27 \%$ \\
$\quad$ Education Bachelor's & 66 & 97 & $46 \%$ \\
$\quad$ Education Master's or higher & & & \\
Languages spoken in the home & 0 & 63 & $18 \%$ \\
No Icelandic spoken in home & 151 & 7 & $45 \%$ \\
Only Icelandic spoken in home & 22 & 103 & $37 \%$ \\
Icelandic and other language(s) spoken & & & \\
Self-assessment of spoken Icelandic fluency & 0 & 59 & $17 \%$ \\
Beginner/Basic & 1 & 43 & $14 \%$ \\
Intermediate & 172 & 75 & $69 \%$ \\
Advanced/Mastered & 76 & 78 & $43 \%$ \\
Parents' working status during March-April (respondents could check more than one) \\
I can work at home & 56 & 54 & $31 \%$ \\
I must leave the house for work & 32 & 31 & $18 \%$ \\
I have a job but I am working less & 12 & 30 & $12 \%$ \\
Unemployed & 35 & 11 & $13 \%$ \\
Other (i.e. maternity leave, student) & & & \\
Provided comments for their decisions (optional) & 79 & 108 & $53 \%$ \\
\hline
\end{tabular}

A total of 403 parents responded to the survey, 47 participants were removed due to incomplete responses. The remaining 356 participants fulfilled the survey criteria, agreed to the terms of the survey, and fully completed the survey (Table 1).

Of the participants who completed the survey, the number of parents born in Iceland and parents born abroad were evenly represented (Table 1). Participants were predominantly female (94\% female), educated, and users of internet and social media, which has implications for the types of generalizations that can be made in this article. This result is consistent with previous research (Auðardóttir \& Rúdólfsdóttir, 2020; Símonardóttir, 2016) about the gendered imbalance of parenting in Iceland. The survey reached all regions of Iceland: $83 \%$ lived in the greater Reykjavík capital area, $4 \%$ in the Northeast, $4 \%$ in the Southwest, $2 \%$ from the West, 2\% in the East, 2\% from the South, $2 \%$ from the Northwest, $1 \%$ from the Westfjords. Parents were asked several questions about how frequently Icelandic was used and how well they comprehended the language. The number of respondents who spoke no Icelandic at home was $63(18 \%)$, while the rest spoke only Icelandic or Icelandic plus another language(s).

Parents who participated had from one to four children in the household and were able to answer for each of their children at the preschool age and compulsory school-age. This accounted for 569 children of which $62 \%$ were in compulsory school and $38 \%$ were preschool aged children. The data indicate that parents' decisions around school operations were closely connected to their work situation. During the mitigation measures of the first wave, people were encouraged to work at home if possible. Almost half, or $43 \%$, of parents reported that they were able to continue to work at home 
and $31 \%$ had to continue working outside the home, with little difference between Icelandic and immigrant parents. About half, or 53\% (187), of participating parents provided write-in comments to elaborate on their responses. In the following section we begin by discussing the result of the quantitative data, which is then supplemented with the analysis of the open-ended questions, and we conclude by reflecting on and answering the research questions.

\section{Findings}

In the quantitative strand parents were asked to rate their confidence in the handling of the pandemic (Table 2). The rapid progression of the pandemic and the short time for authorities to respond created anxiety within society (MMR, 2020a). Anecdotal evidence indicated that parents felt they needed access to information and some immigrant parents with Icelandic language barriers demanded deeper explanations (B. Halldórsdóttir \& E. Lay, personal communication in private Facebook groups, March 2020). Nevertheless, data in Table 2 show that $97 \%$ of Icelanders and $83 \%$ of immigrant parents who responded to the survey felt a high level of confidence in the government's handling of the virus. A chi-squared test for independence indicated that there was no correlation between level of education and level of confidence in the handling of the COVID-19 response; however, due to the high level of education of survey participants this result is inconclusive. The majority of Icelanders (84\%) and $82 \%$ of immigrants surveyed agreed or strongly agreed that the schools were communicating well with parents during this time. (Again, we conducted a chi-square test and found no correlation, p>.1). Interestingly, more immigrants (81\%) reported using the covid.is site than the Icelandic (69\%) respondents. Using the chi squared test we found that there was a stronger correlation between level of education and use of the covid.is site, where $p=.02$ indicating a good fit.

Table 2. Satisfaction with communication among parents during COVID-19.

\begin{tabular}{lcc}
\hline & Born in Iceland & Born Abroad \\
\hline The Icelandic authorities are doing a good job to prevent the spread of COVID-19 \\
Strongly agree & $76 \%(125)$ & $43 \%(74)$ \\
Agree & $21 \%(35)$ & $40 \%(69)$ \\
Neutral & $1 \%(1)$ & $13 \%(22)$ \\
Disagree & $0 \%(0)$ & $3 \%(6)$ \\
Strongly disagree & $2 \%(3)$ & $1 \%(1)$ \\
Total & $(164)$ & $(172)$ \\
I think the school has done a good job communicating with me during this time. \\
Strongly agree & $37 \%(59)$ & $33 \%(56)$ \\
Agree & $47 \%(76)$ & $49 \%(85)$ \\
Neither agree nor disagree & $8 \%(13)$ & $10 \%(17)$ \\
Disagree & $6 \%(9)$ & $6 \%(11)$ \\
Strongly disagree & $2 \%(4)$ & $2 \%(3)$ \\
Total & $(161)$ & $(172)$ \\
I have been using the covid.is website to stay up to date. & & \\
Strongly agree & $34 \%(56)$ & $46 \%(78)$ \\
Agree & $35 \%(57)$ & $35 \%(59)$ \\
Neither agree nor disagree & $16 \%(26)$ & $9 \%(15)$ \\
Disagree & $6 \%(10)$ & $4 \%(6)$ \\
Strongly disagree & $9 \%(14)$ & $7 \%(12)$ \\
Total & $(163)$ & $(170)$ \\
\hline
\end{tabular}


Prior to the modified school schedule on March 16, 172 (30\%) of the respondents' children stayed home from school, 291 (51\%) children stayed at home before the Easter break and 199 (35\%) stayed home after the Easter break (Table 3). By May 4, when schools returned to their normal schedule, only 49 (9\%) children stayed home from school. As can be seen in Table 3, immigrant parents were more likely to keep their children at home at all points, although the difference between the groups was smaller after March 16. Prior to March 16, 62\% of immigrant parents surveyed kept their children at home, compared to $35 \%$ of those parents born in Iceland. During the assembly ban and partial school closures, the difference between the groups decreased significantly but rose again after schools resumed normal operations in May, when 21\% of immigrant parents chose to keep their children at home. Participants indicated several reasons for staying at home in addition to the parents' choice. Several parents cited the labor union strike that coincided with the outbreak. Others detailed instances where children had to stay home and quarantine because of possible exposure. Several parents noted illness unrelated to COVID-19.

Table 3. Total number of children who stayed at home.

\begin{tabular}{lrrr}
\hline & $\begin{array}{r}\text { Parent born } \\
\text { in Iceland }\end{array}$ & $\begin{array}{r}\text { Parent born } \\
\text { abroad }\end{array}$ & Total \\
\hline At home before March 16 & $61(35 \%)$ & $111(62 \%)$ & $172(30 \%)$ \\
At home before Easter (April 9) & $137(78 \%)$ & $154(86 \%)$ & $291(51 \%)$ \\
At home after Easter (April 13) & $90(51 \%)$ & $109(61 \%)$ & $199(35 \%)$ \\
At home after May 4 & $11(6 \%)$ & $38(21 \%)$ & $49(9 \%)$ \\
\hline
\end{tabular}

Parents were asked about concerns during COVID-19 (Table 4). Most parents born in Iceland reported little difficulty accessing information, with a combined 95\% 'disagreeing' or 'strongly disagreeing. There was little difficulty among parents born abroad as well, as a combined $86 \%$ of parents 'disagreed' or 'strongly disagreed' with the statement, "I have difficulty getting information about COVID-19 in Iceland." There were slightly more differences regarding job security. More than half of the Icelandic parents reported no concerns about job security after COVID-19. Whereas only $6 \%$ of Icelandic parents were concerned for their job security, $22 \%$ of immigrants reported being very worried ('strongly agreed') and 20\% were worried ('agreed'). Concern about their children's health and safety showed only slightly differences. One-fifth (20\%) of Icelandic parents were worried and $37 \%$ of immigrant parents were worried about their child's health and safety. 
Table 4. Concern among parents during COVID-19.

\begin{tabular}{lcc}
\hline & Born in Iceland & Born Abroad \\
\hline I have difficulty getting information about COVID-19 in Iceland. & \\
\hline Strongly agree & $3 \%(4)$ & $1 \%(2)$ \\
Agree & $1 \%(1)$ & $3 \%(5)$ \\
Neither agree nor disagree & $1 \%(2)$ & $9 \%(16)$ \\
Disagree & $14 \%(23)$ & $30 \%(52)$ \\
Strongly disagree & $81 \%(131)$ & $56 \%(96)$ \\
Total & $(161)$ & $(171)$ \\
\hline I am worried about my job security after COVID-19. & $6 \%(10)$ \\
\hline Strongly agree & $14 \%(23)$ & $22 \%(37)$ \\
Agree & $18 \%(29)$ & $17 \%(29)$ \\
Neither agree nor disagree & $23 \%(38)$ & $24 \%(42)$ \\
Disagree & $38 \%(62)$ & $17 \%(29)$ \\
Strongly disagree & $(162)$ & $(171)$ \\
Total & $6 \%(9)$ & $11 \%(19)$ \\
I am worried about my child's health and safety while the schools are open. & \\
Strongly agree & $14 \%(24)$ & $26 \%(46)$ \\
Agree & $17 \%(28)$ & $17 \%(29)$ \\
Neither agree nor disagree & $40 \%(64)$ & $30 \%(51)$ \\
Disagree & $23 \%(37)$ & $16 \%(27)$ \\
Strongly disagree & $(162)$ & $(172)$ \\
Total &
\end{tabular}

To better understand or illuminate potential differences between those who reported being born in Iceland and those who did not, we conducted several chi-squared tests based on self-assessment of language skill. As noted in the methods section, this was due to the perceived benefit of having Icelandic language skills. We explored the correlation between language and trust in the authorities' strategies for responding to COVID-19 (see statements in Table 4). Overall, we found no correlation between any of the statements and differences in self-assessed language skills. Due to the skewing effect of Icelandic-born participants, we conducted separate chi-squared tests based on language skill and found that, as noted in the table above, participants not born in Iceland were more likely to report concern over their children's health and safety $(\mathrm{p}=.04 / \mathrm{p}=.03)$. However, whether this was connected to higher or lower levels of language skills is unclear due to the small sample size $(n=165)$. In the following section we explore parents' responses based on the data collected in the qualitative open-ended responses.

\section{Those whose children stayed at home}

Before schools moved to restricted hours after March 16, 85 (24\%) parents in the survey had already started keeping their children at home. A substantial number of respondents who provided comments to their decisions cited practical or personal reasons for keeping their children at home. They commonly reported protecting family members who were elderly or in a high-risk health group, working in a frontline job or with high-risk people, staying at home with COVID-19 symptoms or other illnesses, or having to keep their children home because of the strike. Some older students stayed at home because all of their classes had been moved online. Families had to adjust to irregular school hours: "We live far from the school and there was no point to meet two hours two times a week." Staying at 
home was a convenient solution for those who, "could and wanted to social distance." Another parent, "was working from home and wanted to be more with my kid." These parents' responses indicate they saw pragmatic reasons for remaining at home.

A typical emotional response to a pandemic is fear, which some parents indicated with negative or worried responses, although not many; 27 parents reported fear of the spread of the virus was too much to allow their children to continue at school. Explanations included: "Because this virus was intensifying," "I was hesitant to send my child to school." "Catch the virus and end up in quarantine," "the increase of cases was very worrisome." They were "afraid of him getting exposed." "She is still so young." Two parents reported that their child was too stressed to go to school. Parents also expressed doubts because Iceland's decision contrasted sharply with other country school closures and lockdowns. They made comparisons to their home countries. "Other countries completely closed all schools". Their comments indicated low confidence in the government's decision. "We didn't trust the Gov't decision and did what they were doing in (their home country)". An immigrant parent who started keeping her child home before Easter says, "I figured more cases in the country means more risk of exposure, especially since the fully Icelandic families did not seem to be socially distancing." But Icelandic parents also expressed fear of the virus and stress over what should happen if they became infected. One Icelandic parent says, "It was not safe to send them to pre-school and I was scared of the virus."Some parents acknowledged their vulnerability as immigrants:

"Not enough data to feel secure about bringing our child back to school. We felt like our safety net of friends and family in Iceland was not that strong."

"We do not have a strong social community to provide a backup if we fall seriously ill. The risk was too great until there was empirical data to inform a decision."

"I have no family here to take care of me, so it is of utmost importance that we stay as healthy as possible. Literally a matter of survival."

These immigrant parents were keenly aware of their lack of resources should they become ill. Without a support network of family or close friends, parents cannot as easily agree to send their children to school with the threat or risk of infection. Despite the reassurances of the health officials that children are low risk, those parents indicating weak ties in the network cannot rely on reciprocated trust and support.

Even though the number of active infections began to rapidly decrease after April 5, 148 (42\%) parents reported keeping their children home before the Easter holiday break, or $51 \%$ of the total children in the survey (Table 3). The number dropped to 97 (27\%) parents who continued to keep their children home after the Easter holiday break. Following seven weeks of a restricted schedule, all preschools and compulsory schools resumed normal school operations on May 4. Only 16 parents reported keeping their children home at this time, the majority of them being immigrant parents. The reasons included either the union strike that resumed and closed some schools, or an ongoing fear of the virus.

"Strike again, now they are back to school since we trust that the authorities evaluate the situation thoroughly. We can do that due to the impressive amount of information available."

"Still too soon to go back to normal."

However, the most common reason for parents keeping their children home was based on an intrinsic sense of altruism. We found these parents, both Icelandic and immigrant, to be self-disciplined by following strict social distancing rules and showing agency in their decisions as parents. Icelandic parents emphasized protecting the family and school: 
"This is the first time as a foreigner that I have had such a strong connection to the state":

Parents' voices on Icelandic school staying open in the time of COVID-19

"I just felt better to have them at home and not increase the risk."

"To reduce the load for the preschool, to reduce our stress."

"Mainly to relieve the pressure on schools and teachers."

This sentiment of selflessness or self-preservation was also represented among immigrant parents but from a different perspective. Immigrant parents expressed a combination of caution and responsibility:

"To reduce the risk of bringing the virus home while, simultaneously, alleviate the burden on teachers and staff."

"There were many unknowns, but it was possible that asymptomatic children could be contagious, and we wanted to do what was safest for our family and for the school community and community at large."

"We wanted to do our part to keep people safe, even if class was operating at school every day."

While both Icelandic and immigrant parents commented on helping schools and teachers, only immigrant parents interpreted their decision as doing their part to help the broader community. Immigrant parents found comfort in being responsibly safe "for everyone's safety" as a "contribution for society's safety and well-being."

\section{Those whose children stayed in school}

We now examine the motivations of the large majority of parents in the survey who allowed their children to stay in school during the first wave of the pandemic. Again, there were a number of parents who gave practical or personal reasons such as, "parents had to work and the other parent is in the frontline." About one-quarter of respondents who allowed their children to stay in school connected their decision to work obligations: "Both parents working from home. We need all the childcare we can get to be productive." Icelandic and immigrant parents alike also said that they could not afford to stay home because they "cannot be away from work after the strike earlier which finished all my vacation days" or "because of work there was no option of staying home." Parents also indicated that network ties limited their choices: "We all needed to get back to work and had no one to look after our child."

Another popular response was from the group of parents who "didn't consider the threat to be high" and "saw no reason to" keep children at home. "We're not in the risk group" "child was not ill and I was not worried about the disease," so they "don't think it was necessary." This type of passive emotional attitude requires a considerable amount of trust and embeddedness in a network (Larsen et al., 2004), even though they did not explicitly indicate trust as a reason when other respondents did. They exhibited optimism, maintaining a positive outlook with their peers and supporting one another in their decision.

Some parents pointed to the low infection rate of children and did not see any risk to their children. "Children are relatively safe from covid-19." "He is healthy and no need to miss school." The child's wellbeing and need for regularity, routine and socialization also influenced parents' decisions:

"Don't see a reason to, school activities and routine are important. Children in schools don't seem to be at risk regarding the spread of COVID." (Icelandic parent)

"He has adhd and needs the routine and stimulation." (Icelandic parent)

"Great to meet their friends." (Icelandic parent)

"School rules work very well, number of cases decreased, single kid needs to have social interactions with other kids after all this time." (Immigrant parent) 
"Because it is important that kids keep their routine and meet people their age for mental health." (Immigrant parent)

"Child did not want to miss out on the school curriculum." (Immigrant parent)

It is often a combination of all these factors that influence parents' decisions. An Icelandic mother writes, "They are low risk at getting or spreading the virus. And also I had more responsibility at work so I had to work a lot." The social pressure from parents' networks and the greater community was expressed by both Icelandic and immigrant parents. One Icelandic parent said, "I was very anxious. It wouldn't fare well to do anything different from peers." However, this pressure to comply with the normative was more commonly perceived positively as an act of solidarity. An immigrant parent says, "My children were very happy to go to school for a short while. I believe this is the first time as a foreigner that I have had such a strong connection to the state."

Overwhelmingly, the most common response given by parents for allowing their children to stay in school was deep trust in the authorities' decisions and recommendations. "Trust" accounted for more than half of the responses from parents who allowed their children to stay in school. "I trusted the authorities." "I trust the doctors that say it is no risk." "If it was needed to stay home, they would say that." "I trust the recommendations made and was happy that they got to keep at least a bit of routine." By the time regular school hours resumed after May 4, 95\% of the parents responded that they had sent their children back to school. A minority of parents showed frustration because they still did not feel it was safe:
"We are forced to send the child to school."
"Cause I've got the e-mail that schools are opening and every kid must go to school.
"We are sending the child the min. number of hours (4) as we are forced to pay for it."
"Because compulsory attendance kicked in, if it hadn't the child would still be home."

The comments from these parents show several influencing factors that caused them to send their children to school against their own feelings of distress. Teachers and schools expected students to return to normal school hours. Some parents felt coerced to adhere, although it is not known whether they could have negotiated with the school based on their concerns with the pandemic. On the whole, economic strain and job security have been amplified in pandemic times, and many respondents had cited work as a primary factor in their decisions to send their children back to school.

\section{Discussion and Conclusion}

In this study, we aimed to understand the reactions of parents in Iceland to the authorities' pandemic response strategy and subsequent school operations. Our study indicates that many parents who participated in the survey opted to follow the recommendations of the authorities to keep children in school during the pandemic, which led to swift collective action. This strategy of keeping schools open contrasted with actions taken in other countries and was therefore questioned by some parents, particularly those with weak or bridging ties to Icelandic society, and drew comparisons with other countries, such as the US, UK and various European countries which entirely closed schools (UNESCO, 2020a, 2020b). Rather than enforcing strict regulations on people's social behavior, the strategy of the Icelandic authorities was to encourage appropriate social behavioral change with as little disruption to pre-existing social norms as possible. This meant allowing children to continue, at least partially, the steady routine of schooling. Displaying high levels of institutional trust, both Icelandic and immigrant parents found it easy to follow the behavior of the majority, thereby making the impact of the moral nudge (Capraro et al., 2019) towards pro-social behavior more effective in favor of the authorities' recommendations. 
"This is the first time as a foreigner that I have had such a strong connection to the state":

Parents' voices on Icelandic school staying open in the time of COVID-19

While there was a difference between the two parent groups, native Icelandic and immigrant, this difference was not significant in terms of trust in the authorities and school operations. In looking at correlations between Icelandic language skills and country of origin, the data did not indicate a significant relationship, thus our data do not indicate a lack of institutional trust within the sample populations. People perceived the authorities' decisions as positive and proactive, creating a sense of shared common identity as a desirable approach. As one participant pointed out, the response strategy was the first time they felt a genuine sense of belonging. Our findings indicate that routes taken both with the Directorate of Health and within the school system were effective ways to promote cooperative behavior, both among Icelandic and immigrant parents. Parents in this study preferred to be optimistic and support the authorities' decisions to counterbalance negative feelings of doubt or anxiety.

While collective action was expedited by trust, social norms, and reciprocity, Icelandic parents reported their willingness to comply with authorities' recommendations because they were accompanied by credible, evidence-based information offered by experts. Immigrant parents, on the other hand, did acknowledge a lack of network support as they did not see themselves as embedded with the bonded networks. However, immigrants who were more embedded, particularly having higher language competencies, exhibited bonding and bridging ties that facilitated social cohesion. Conforming to social norms is easier for those who are more embedded in the network (Lin \& Ao, 2008) and were already benefiting and receiving practical, social support from the network before the pandemic. The longer individuals are part of a community, the more likely they are to have participated in social activities and have increased social ties (Larsen et al., 2004). Additionally, where immigrant parents based their decisions on protecting the wider network, Icelandic parents spoke in terms of protecting immediate family.

Parents' social networks are made up of overlapping bonding and bridging ties. Consistent with past research, the efficiency of bridging ties to mobilize collective action depends upon the existence of strong bonding ties. Those with a social network of supporting family and friends, including immigrants who have lived in the country for a long time (Larsen et al., 2004; Sampson, 1988), are more likely to belong to tight-knit networks with bonding ties and share a similar set of social attitudes, as was indicated in the responses of parents in this study who demonstrated significant trust in the authorities (see Table 2). Our data indicate that the parents with bonding and bridging ties were activated during the first wave of the pandemic, found encouragement and were spurred into responding with a shared sense of purpose and societal approval.

The study offers insight into the engagement of Icelandic and immigrant parents using a social capital approach, but the data set has several limitations, given the rapid development of the pandemic and the unusual preventative measures of keeping schools open. This study did not find access of information to be a factor among its participants. However, the manner in which the survey was conducted meant that participants were likely to already be frequently using the internet and social media, thus keeping abreast of pandemic updates. This, as well as distributing the survey in only Icelandic and English, might explain why well-educated and female parents were over-represented in the sample.

The findings in this study have considerable implications for school administrators, teachers, parents, and educational policy makers. Education researchers are increasingly focusing their attention on the social well-being of immigrant families, and our findings reinforce the importance of conveying trust within the community to ensure social cohesion. While parents in this study displayed high levels of trust in the authorities and schools, we have highlighted the significance of bringing proper information access to all parents to maintain confidence among parents and their children. Future work in this field will focus on perspectives among the different school levels of children, specifically preschools and compulsory schools, and a deeper examination of the factors that impacted immigrant parents. 
It can be argued that Iceland's successful response to the first wave could not have been possible without institutional trust. After all, the official recommendations were not asking for a dramatic change in social behavior. This is certainly one reason that aggressive mitigation measures were avoided. The risk perception during the first wave was low compared to other countries. At the time of the study, only a minimum of preventative measures such as social distancing had been introduced. More imposing measures, such as mask wearing, were not yet enforced. One of the strategies the authorities emphasized was the importance of socialization and staying involved and engaged with the community. In this way, people who do not belong in dense networks were discouraged from isolating themselves, especially during the time when there was a need for physical distancing and a decrease in gatherings and communal activities. This was further supported by Icelandic media and publications from the state, promoting pro-social behavior and a "We're all in this together" sensibility with a minimum of negative news that would foster divisiveness. Trust in the authorities was essentially endorsed and coupled with the expectation of societal approval. As a result, strong societal pressure and public confidence in government and health agencies won over some of those concerns brought on by the pandemic.

\section{„Petta er í fyrsta skipti sem ég, sem útlendingur, hef svo sterk tengsl við hið opinbera“: Raddir foreldra um að íslenskir skólar héldust opnir á tímum COVID-19}

Ísland var eitt fárra landa par sem leik- og grunnskólum var haldið opnum að hluta til á meðan fyrsta bylgja COVID-19 heimsfaraldursins reið yfir. Markmið pessarar rannsóknar er að kanna hvernig foreldrar brugðust við ákvörðun stjórnvalda um að halda áfram skólastarfi barna á hamfaratímum. Markmiðið var að skilja sjónarhorn foreldra út frá trausti, aðgengi að upplýsingum og tengslaneti, með pví að spyrja hvernig peir fengu aðgang að upplýsingum frá íslenskum stjórnvöldum á pessum tíma og hvernig peir túlkuðu pær. Við beittum kenningunni um félagsauð (e. social capital theory) til að skoða hve mikið traust foreldrar bera til stjórnvalda út frá félagslegum og fjárhagslegum áhyggjum peirra. Gengið var út frá tvenns konar félagslegum tengslanetum, annars vegar tengjandi tengslum (e. bonding ties) og brúandi tengslum (e. bridging ties), til að greina tengsl innan einstakra félagslegra hópa og á milli peirra (Bankston, 2014; Putnam, 1995). Tengjandi tengsl eru náin sambönd sem einstaklingur hefur beinan aðgang að og hjálpa til við að verja einstaklinginn gegn einangrun. Brúandi tengsl eiga hins vegar við sambönd par sem tengslin eru lausari og síður áhættusöm en mögulega mikilvægari pegar kemur að öflun upplýsinga eða til að ná ákveðnu markmiði (Putnam, 1993). Pessi tvípætta nálgun á tengsl er gagnleg pegar kemur að pví að rannsaka fjölbreytileg samfélög, par sem tengslanet skarast og verka pá á grundvelli bæði tengjandi og brúandi félagsauðs. Skjótar sameiginlegar aðgerðir eru háðar bæði tengjandi og brúandi tengslum.

Við lögðum netkönnun fyrir íslenska og alpjóðlega foreldra sem var opin frá 10. maí til 8. júní 2020. Вæði eigindlegum og megindlegum upplýsingum var safnað um aðgengi að fréttum um COVID-19, upplifun á skólastarfi, skilning foreldra á viðbrögðum við heimsfaraldrinum hérlendis, ásamt lýðfræðilegum upplýsingum. Flestir pátttakendur voru háskólamenntaðar konur. Um helmingur pátttakenda voru innfæddir Íslendingar og helmingur var af erlendum uppruna. Foreldrar gátu svarað fyrir hvert barna sinna á leikskólaaldri (38\%) og grunnskólaaldri (62\%). Af börnum peirra 356 foreldra sem luku könnuninni voru 172 börn (30\%) heima áður en kom að breyttu fyrirkomulagi skólahalds, 16. mars, 291 barn (51\%) var heima fyrir páskafrí og 199 börn (35\%) voru heima eftir páskafrí. Pegar skólahald hófst aftur með eðlilegum hætti, 4. maí, voru aðeins 49 börn (9\%) heima.

Niðurstöðurnar gefa til kynna að flestir af íslensku og margir af albjóðlegu foreldrunum báru mikið traust til stjórnvalda og hvernig pau tókust á við faraldurinn. Flestir foreldrar leyfðu börnum sínum að halda áfram í skólanum, einkum vegna pess að peir treystu 
"This is the first time as a foreigner that I have had such a strong connection to the state":

Parents' voices on Icelandic school staying open in the time of COVID-19

ákvörðunum yfirvalda. Aðrar ástæður voru m.a. heilsufarslegar, skuldbindingar vegna vinnu og litlar áhyggjur af veirunni. Foreldrarnir sem héldu börnum sínum heima nefndu einnig heilsufarslegar ástæður og skuldbindingar vegna vinnu. Par að auki nefndu foreldrar einnig ótta og skort á stuðningsneti. Hins vegar var umhyggja fyrir hag annarra algengasta ástæða pess að foreldrar héldu börnum sínum heima. Á meðan bæði íslenskir og alpjóðlegir foreldrar nefndu pað að hjálpa skólum og kennurum, voru pað eingöngu alpjóðlegir foreldrar sem túlkuðu ákvörðun sína sem svo að peir væru að leggja sitt af mörkum til að hjálpa samfélaginu í heild sinni. Við teljum að íslenskir foreldrar hafi djúp tengjandi tengsl í tengslaneti fjölskyldu og vina ásamt félagsauði til að vernda pessi tengsl. Íslenskir foreldrar hafa einnig sterk tengsl við félagshætti landsins. Foreldrar af erlendum uppruna byggja félagsauð í gegnum brúandi tengsl. Peirra hagur er að vernda víðtækara tengslanet (Ryan o.fl., 2008) vegna pess að mögulega upplifa peir sig ekki sem hluta af péttriðnu tengslaneti innfæddra.

Rannsókn okkar sýnir að prátt fyrir áhyggjur af að útsetja börn sín frekar fyrir smiti, ákváðu flestir foreldrar að fylgja ráðleggingum yfirvalda um að halda börnunum í skóla sem síðan auðveldaði skjótari viðbrögð. Pessi stefna var ólík stefnu ýmissa annarra landa og efuðust pví sumir foreldrar um hana, sérstaklega peir sem höfðu veik tengsl við samfélagið. Frekar en að beita ströngum reglugerðum varðandi félagslega hegðun fólks, var stefna íslenskra stjórnvalda að hvetja til viðeigandi breytinga á félagslegri hegðun með eins litlum truflunum á félagsháttum og kostur var. İ pví fólst að leyfa börnum að halda áfram reglubundinni skólagöngu, alla vega að hluta til.

Félagsleg tengslanet foreldra eru samsett af tengjandi og brúandi tengslum sem skarast. Eins og fyrri rannsóknir gefa vísbendingar um, gagnast tengjandi tengsl við að tryggja félagslegan stuðning og brúandi tengsl gagnast pegar kemur að samræmdum sameiginlegum aðgerðum. Sterkur samfélagslegur prýstingur til að fylgja félagsháttum og félagslegri hegðun leiddi af sér farsæl viðbrögð við fyrstu bylgjunni á Íslandi.

Efnisorð: COVID-19 á Íslandi, traust almennings, skólastarf, foreldrar, félagsauður, félagsnet

\section{Um höfunda}

Elizabeth B. Lay (elizabeth@hi.is) er doktorsnemi við Menntavísindasvið Háskóla Íslands. Hún er með M.A.-próf í alpjóðlegu námi í menntunarfræði frá Háskóla Íslands. Doktorsáhersla hennar er á pátttöku foreldra sem eru innflytjendur í íslenska menntakerfinu með pví að nota menningar- og félagsauður og samtvinnun. Hún vinnur nú í rannsóknarverkefni um að skoða skóla án aðgreiningar í fjölbreyttu námsumhverfi.

Brynja Elísabeth Halldórsdóttir (brynhall@hi.is) lauk doktorsprófi við Minnesotaháskóla 2012 í alpjóðamenntunarfræðum með áherslu á fjölmenningu og jafnræðishugmyndir fyrir jaðarhópa í skólum og pjóðfélögum. Hún starfar nú sem lektor í Deild menntunar og margbreytileika par sem hún sinnir kennslu og námsbrautarformaður albjóðlegsnáms í menntunarfræði. Brynja stundar rannsóknir á stöðu og reynslu innflytjenda í íslensku samfélagi og í gagnrýnum menntunarfræðum.

\section{About the authors}

Elizabeth B. Lay (elizabeth@hi.is) is a doctoral student in the School of Education at the University of Iceland. She holds an M.A. in International Studies in Education from the University of Iceland. Her PhD focus is on immigrant parent participation in the Icelandic education system using cultural and social capital and intersectionality. She is currently involved in a research project on inclusive practices in diverse educational settings. 
Brynja E. Halldórsdóttir (brynhall@hi.is) is the Chair of the Department of International Studies of Education at the University of Iceland. She holds a doctorate in Comparative International Development Education from the University of Minnesota. Her research areas include understanding institutional and structural racism and immigrant positionality in diverse societies.

\section{Notes}

${ }^{1}$ Efling is one of the largest trade unions in Iceland, with a wide range of members working in factories, the health sector, food sector, hotels and restaurants, and public service. Efling Union and Reykjavík City reached a deal to end a strike of 1,800 union members that began in early February 2020 on selected days and in full on February 17. The strike had affected operations of preschools, trash removal, snow removal and road repairs. On March 9, a strike by about 300 Efling members who work in municipalities outside of Reykjavík began. Because cleaning and support staff in compulsory schools were affected by the strike, several schools closed in mid-March amidst the COVID-19 restrictions.

${ }^{2}$ The Icelandic education system is partially decentralized. While municipalities are responsible for preschool (ages 2-5) and compulsory (ages 6-15) education, the central government is responsible for running upper secondary (ages 16-19) and higher education (age 20+) institutions.

\section{Acknowledgements}

The authors are grateful to Porsteinn Aðalsteinsson for his assistance in data calculations, Charlotte Wolff and Gísli Harðarson for their assistance with reading the paper, numerous proofreaders and the anonymous reviewers for their useful comments and recommendations that have added to the cogency of this manuscript. The authors also acknowledge financial support from 'Getting a feel for the game' UI Research Fund in conducting the online survey.

\section{References}

Armitage, R., \& Nellums, L. B. (2020). Considering inequalities in the school closure response to COVID-19. The Lancet Global Health, 8(5), e644. https://doi.org/10.1016/S2214-109X(20)30116-9

Árnason, E. P. (2020, March 19). Segir að útgöngubann myndi valda gríðarlegum skaða [Says that a curfew would cause enormous damage]. vísir. https://www.visir.is/g/202022451d/segir-ad-utgongubann-myndivalda-gridarlegum-skada

Auðardóttir, A. M., \& Rúdólfsdóttir, A. G. (2020). Chaos ruined the children's sleep, diet and behaviour: Gendered discourses on family life in pandemic times. Gender, Work \& Organization. https://doi.org/10.1111/ gwao. 12519

Bankston, C. L. (2014). Immigrant networks and social capital. Polity Press.

Bjarnason, F. (2020, March 13). Samkomubann á Íslandi [Assembly ban in Iceland]. mbl.is. https://www.mbl. is/frettir/innlent/2020/03/13/samkomubann_a_islandi/

Bjarnason, T. (2014). Traust í kreppu: Traust til Alpingis, lögreglu, stjórnmálamanna og forseta Íslands í kjölfar hrunsins [Trust in a crisis: Confidence in parliament, the police, politicians and the president of Iceland in the wake of the financial collapse]. Íslenska pjóðfélagið, 5(2), 19-38. https://thjodfelagid.is/index.php/Th/ article/view/67

Braun, V., \& Clarke, V. (2013). Successful qualitative research: A practical guide for beginners. SAGE. 
"This is the first time as a foreigner that I have had such a strong connection to the state":

Parents' voices on Icelandic school staying open in the time of COVID-19

Burgess, S., \& Sievertsen, H. H. (2020, April 1). Schools, skills, and learning: The impact of COVID-19 on education. VoxEU.org. https://voxeu.org/article/impact-covid-19-education

Capraro, V., Jagfeld, G., Klein, R., Mul, M., \& van de Pol, I. (2019). Increasing altruistic and cooperative behaviour with simple moral nudges. Scientific Reports, 9(1), 11880. https://doi.org/10.1038/s41598-01948094-4

Creswell, J. W., \& Plano Clark, V. L. (2011). Designing and conducting mixed methods research (2nd ed.). SAGE.

Delhey, J., \& Newton, K. (2003). Who trusts? The origins of social trust in seven societies. European Societies, 5(2), 93-137. https://doi.org/10.1080/1461669032000072256

Dinesen, P. T. (2011). A note on the measurement of generalized trust of immigrants and natives. Social Indicators Research, 103(1), 169-177. https://doi.org/10.1007/s11205-010-9704-6

Dinesen, P. T. (2013). Where you come from or where you live? Examining the cultural and institutional explanation of generalized trust using migration as a natural experiment. European Sociological Review, 29(1), 114-128. https://doi.org/10.1093/esr/jcr044

Doyle, O. (2020). COVID-19: Exacerbating educational inequalities? UCD Geary Institute for Public Policy. https://publicpolicy.ie/downloads/papers/2020/COVID_19_Exacerbating_Educational_Inequalities.pdf

Einarsdóttir, P., Heijstra, T. M., \& Rafnsdóttir, G. L. (2018). The politics of diversity: Social and political integration of immigrants in Iceland. Stjórnmál og stjórnsýsla, 14(1), 131-148. https://doi.org/10.13177/ irpa.a.2018.14.1.6

Embætti landlæknis. (2020). Tillögur sóttvarnalaknis til heilbrigðisráðherra [Recommendations of the epidemiologist to the Minister of Health]. https://www.stjornarradid.is/library/04-Raduneytin/Heilbrigdisradu neytid/ymsar-skrar/Till\%c3\%b6gur\%20s\%c3\%b3ttvarnal\%c3\%a6knis\%20til\%20heilbrig\%oc3\%b0is r\%c3\%a1\%c3\%b0herra.pdf

Embætti landlæknis og almannavarnadeild ríkislögreglustjóra. (n.d.). Upplýsingar um Covid-19 á Íslandi [Information on COVID-19 in Iceland]. https://www.covid.is

Félagsmálaráðuneytið. (2007). Stefna um aðlögun innflytjenda [Strategic plan regarding the assimilation of immigrants]. https://www.stjornarradid.is/media/velferdarraduneyti-media/media/acrobat-skjol/Stefna_um_ adlogun_innflytjenda.pdf

Fukuyama, F. (2001). Social capital, civil society and development. Third World Quarterly, 22(1), 7-20. https:// doi.org/10.1080/713701144

Granovetter, M. (1973). The strength of weak ties. The American Journal of Sociology, 78(6), 1360-1380.

Granovetter, M. (1983). The strength of weak ties: A network theory revisited. Sociological Theory, 1, 201-233. https://doi.org/10.2307/202051

Gunnpórsdóttir, H., Barillé, S., \& Meckl, M. (2019). The education of students with immigrant background in Iceland: Parents' and teachers' voices. Scandinavian Journal of Educational Research, 63(4), 605-616. https://doi.org/10.1080/00313831.2017.1415966

Harðardóttir, E., \& Magnúsdóttir, B. R. (2018). „Að preifa sig áfram í myrkrinu“: Ríkjandi stefnur og straumar um ungt flóttafólk í íslensku grunn- og framhaldsskólakerfi ["Moving in the dark”: Exploring representations of refugee youth through Icelandic public policy documents and teachers' narratives]. Stjórnmál og stjórnsýsla, 14(3), 183-204. https://doi.org/10.13177/irpa.a.2018.14.3.2

Holm, H. (2020, April 1). Reyna að ná til útlendinga vegna COVID-19 [Trying to reach foreigners for COVID-19]. ruv.is. https:/www.ruv.is/frett/2020/04/01/reyna-ad-na-til-utlendinga-vegna-covid-19

Ingvarsson, Á. (2020, July 27). Svar[ts]ýnisalda hugsanleg [Possible wave of pessimism]. Morgunblaðið, A12. Johannessen, K. (2020, April 1). Heilu fjölskyldurnar einangrað sig [Whole families isolated]. Morgunblaðið, A2.

Jóhannesson, G. P., Skaptadóttir, U. D., \& Benediktsson, K. (2003). Coping with social capital? The cultural economy of tourism in the north. Sociologia Ruralis, 43(1), 3-16. https://doi.org/10.1111/1467-9523.00226

Jónsson, J. P. (2020, March 6). Fyrstu innlendu smitin - lýsa yfir neyðarstigi [First domestic infections -emergency declared].mbl.is. https://www.mbl.is/frettir/innlent/2020/03/06/fyrstu_innlendu_smitin_lysa_yfir_neydar stigi/

Karvelsdóttir, S., \& Guðjónsdóttir, H. (2010). Raddir kennara sem kenna fjölbreyttum nemendahópum [Voices of teachers who teach diverse groups of students]. Rádstefnurit Netlu-Menntakvika 2010. https://netla.hi.is/ serrit/2010/menntakvika2010/022.pdf 
Knack, S. (2003). Groups, growth and trust: Cross-country evidence on the Olson and Putnam hypotheses. Public Choice, 117(3/4), 341-355. https://doi.org/10.1023/B:PUCH.0000003736.82456.04

Kumlin, S., \& Rothstein, B. (2010). Questioning the new liberal dilemma: Immigrants, social networks, and institutional fairness. Comparative Politics, 43(1), 63-80. https://doi.org/doi:10.5129/00104151 0X12911363510394

Larsen, L., Harlan, S. L., Bolin, B., Hackett, E. J., Hope, D., Kirby, A., Nelson, A., Rex, T. R., \& Wolf, S. (2004). Bonding and bridging: Understanding the relationship between social capital and civic action. Journal of Planning Education and Research, 24(1), 64-77. https://doi.org/10.1177/0739456X04267181

Lay, E. (2016). Parents reaching beyond home: Dispositions of immigrant parents towards their young adolescent's academic experiences [MA thesis]. University of Iceland, School of Education.

Lin, N. (2000). Inequality in social capital. Contemporary Sociology, 29(6), 785-795.

Lin, N. (2008). A network theory of social capital. In D. Castiglione, J. W. Van Deth, \& G. Wolleb (Eds.), The handbook of social capital (pp. 50-69). Oxford University Press.

Lin, N., \& Ao, D. (2018). The invisible hand of social capital: An exploratory study. In N. Lin \& B. Erickson (Eds.), Social capital: An international research program (pp.107-132). Oxford University Press.

Logadóttir, S. Ó. (2020, March 23). „Mjög lítið smit meðal barna“ [“Very low infection among children”]. Kjarninn. https://kjarninn.is/frettir/2020-03-23-mjog-litid-smit-medal-barna/

Magnúsdóttir, N. (2010). „Allir vilja eignast islenskar vinir“" Hverjar eru helstu hindranir á vegi erlendra grunn- og frambaldsskólanemenda i islensku skólakerfi ["Everyone wants to have Icelandic friends": What are the main hindrances for immigrant students in primary and secondary schools in Iceland?] [M.Ed. thesis]. University of Iceland, School of Education.

Magnússon, H. D. (2020, March 17). Berum samfélagslega ábyrgð [It is our social responsibility]. mbl.is. https:// www.mbl.is/frettir/innlent/2020/03/17/berum_samfelagslega_abyrgd/

MMR. (2020a, March 25). Meiri áhyggjur af efnahag en heilsufari [More concerned with economy than health]. Market and Media Research. https://mmr.is/frettir/birtar-nieurstoeeur/819

MMR. (2020b, March 27). Afgerandi traust til almannavarna og heilbrigðisstofnana [Strong confidence in civil protection and public health institutes]. Market and Media Research. https://mmr.is/frettir/birtarnieurstoeeur/820-afgerandi-traust-til-almannavarna-og-heilbrigdhisstofnana

Moseholm, E., \& Fetters, M. D. (2017). Conceptual models to guide integration during analysis in convergent mixed methods studies. Methodological Innovations, 10(2), 2059799117703118. https://doi. org/10.1177/2059799117703118

Nannestad, P. (2008). What have we learned about generalized trust, if anything? Annual Review of Political Science, 11(1), 413-436. https://doi.org/10.1146/annurev.polisci.11.060606.135412

Nannestad, P., Svendsen, G. T., Dinesen, P. T., \& Sønderskov, K. M. (2014). Do institutions or culture determine the level of social trust? The natural experiment of migration from non-western to western countries. Journal of Ethnic and Migration Studies, 40(4), 544-565. https://doi.org/10.1080/1369183X.2013.830499

Ólafsdóttir, G., Ragnarsdóttir, H., \& Hansen, B. (2012). Hvað má læra af farsælli reynslu priggja grunnskóla af fölmenningarlegu starfi? [What is to be learnt from three primary schools' successful experience of multicultural work?] Uppeldi og menntun, 21(1), 29-51.

Ómarsdóttir, A. (2020, April 19). Erlendir ríkisborgarar einungis 4\% smitaðra [Foreign nationals make up only 4\% of infections]. ruv.is. https://www.ruv.is/frett/2020/04/19/erlendir-rikisborgarar-einungis-4-smitadra

Ortiz, A. (2020, April 10). Iceland's 'Test Everyone' goal has skeptics, but it may be working. The New York Times. https://www.nytimes.com/2020/04/09/world/europe/coronavirus-testing-iceland.html

Ostrom, E., \& Ahn, T. K. (2009). The meaning of social capital and its link to collective action. In G. T. Svendsen \& G. L. H. Svendsen (Eds.), Handbook of social capital: The troika of sociology, political science and economics (pp. 17-35). Edward Elgar Publishing Limited.

Pearce, N., Lawlor, D. A., \& Brickley, E. B. (2020). Comparisons between countries are essential for the control of COVID-19. International Journal of Epidemiology, 49(4), 1059-1062. https://doi.org/10.1093/ije/dyaa108

Pitas, N., \& Ehmer, C. (2020). Social capital in the response to COVID-19. American Journal of Health Promotion, 34(8), 942-944. https://doi.org/10.1177/0890117120924531 
"This is the first time as a foreigner that I have had such a strong connection to the state":

Parents' voices on Icelandic school staying open in the time of COVID-19

Price, S. (2020, July 23). Controlling and preventing infection spread in Iceland. Health Europa. https://www. healtheuropa.eu/controlling-and-preventing-infection-spread-in-iceland/101614/

Putnam, R. D. (1993). The prosperous community. The American Prospect, 4(13), 35-42.

Putnam, R. D. (1995). Bowling alone: America’s declining social capital. Journal of Democracy, 6(1), 65-78.

Putnam, R. D. (2001). Bowling alone. Simon and Schuster.

Ríkisendurskoðun. (2015). Málefni útlendinga og innflytjenda á Íslandi [Issues relating to foreigners and immigrants in Iceland]. https://rikisendurskodun.is/wp-content/uploads/2016/01/utlendingar_innflytjendur.pdf

Röder, A., \& Mühlau, P. (2012). Low expectations or different evaluations: What explains immigrants' high levels of trust in host-country institutions? Journal of Ethnic and Migration Studies, 38(5), 777-792. https:// doi.org/10.1080/1369183X.2012.667986

Runarsdottir, E. M., \& Vilhjalmsson, R. (2015). Ethnic differences in youth well-being: The role of sociodemographic background and social support. Scandinavian Journal of Public Health, 43(6), 580-587. https:// doi.org/10.1177/1403494815588644

Ryan, L., Sales, R., Tilki, M., \& Siara, B. (2008). Social networks, social support and social capital: The experiences of recent Polish migrants in London. Sociology, 42(4), 672-690. https://doi.org/10.1177/0038038508091622

Sævarsdóttir, A. L., Hreiðarsdóttir, A. E., \& Gunnpórsdóttir, H. (2013). Foreldrasamstarf og fjölmenning: Samskipti deildarstjóra í leikskóla við erlenda foreldra sem ekki tala íslensku [Multicultural parent-school collaboration: Perspectives of pedagogical leaders in preschools on communicating with non-native parents who do not speak Icelandic]. Netla - Veftimarit um uppeldi og menntun. https://netla.hi.is/greinar/2013/ ryn/016.pdf

Sampson, R. J. (1988). Local friendship ties and community attachment in mass society: A multilevel systemic model. American Sociological Review, 53(5), 766-779. https://doi.org/10.2307/2095822

Samson, I. M. (2014). Foreldrasamstarf i leikskóla [Parental cooperation in preschool] [M.Ed. thesis, University of Iceland, School of Education]. http://hdl.handle.net/1946/20015

Sigurðardóttir, Á. R. (2020). Styðja i stað pess að stjórna: Páttur félags- og menningarauðs i námi og menntun barna með fölmenningarlegan bakgrunn [Supporting instead of managing: The role of social and cultural capital in education for children with multicultural background in Iceland] [MA thesis, University of Iceland, School of Education]. http://hdl.handle.net/1946/34991

Símonardóttir, S. (2016). Constructing the attached mother in the "world's most feminist country”. Women's Studies International Forum, 56, 103-112. https://doi.org/10.1016/j.wsif.2016.02.015

The virus that shut down the world: 2020, a year like no other. (2020, December 24). UN News. https://news. un.org/en/story/2020/12/1080702

UNESCO. (2020a, March 4). Education: From disruption to recovery. https://en.unesco.org/covid19/educationresponse

UNESCO. (2020b). Anticipated impact of COVID-19 on public expenditures on education and implication for UNESCO work. https://unesdoc.unesco.org/ark:/48223/pf0000373276

Wilson, C. A., \& Aðalbjarnardóttir, A. T. (Eds.). (2019). Jafnrétti innflytjenda á atvinnumarkaði [Equality of immigrants in the labour market]. Réttur Aðalsteinsson \& Partners.

Wong, A. S. Y., \& Kohler, J. C. (2020). Social capital and public health: Responding to the COVID-19 pandemic. Globalization and Health, 16(1), 88. https://doi.org/10.1186/s12992-020-00615-x

Pingsályktun nr. 63/145. (2015-2016). Framkvæmdaáætlun í málefnum innflytjenda [Comprehensive action plan in matters relating to immigrants] 2016-2019. https://www.althingi.is/altext/145/s/1692.html

Pingsályktunartillaga nr. 38/150. (2019-2020). Mótun stefnu sem eflir fólk af erlendum uppruna til pátttöku í samfélaginu [Forming a policy to encourage the social participation of people of foreign origin]. https:// www.althingi.is/altext/150/s/0038.html

Prastardóttir, R. (2020, March 12). Skólar farnir að búa sig undir mögulegar lokanir [Schools prepare for possible closures]. mbl.is. https://www.mbl.is/frettir/innlent/2020/03/12/skolar_farnir_ad_bua_sig_un dir_mogulegar_lokanir/

Prír leikskólar og tveir grunnskólar lokaðir í Reykjavík [Three preschools and two compulsory schools closed in Reykjavík]. (2020, March 19). mbl.is. https://www.mbl.is/frettir/innlent/2020/03/19/thrir_leikskolar_ og_tveir_grunnskolar_lokadir_i_rey/ 


\section{Appendix: Online Survey for Parents}

Q1 The survey consists of questions about your background, the impact of COVID-19 on you and your family, and your responses during the course of the pandemic.

There are no right or wrong answers, only your opinion.

You are not obligated to participate in the study.

You do not need to answer a question if you do not want to.

You can drop out of this survey at any time.

The information from the survey will only be used for research and help contribute to policy development.

The information from the survey will remain confidential and cannot be traced to individual participants.

Do you agree to participate in the survey?

Q2 Where do you live?

Capital region / Höfuðborgarsvaðið

Southwest / Sudvesturland

West / Vesturland

Westfjords / Vestfirdir

Northwest / Nordvesturland

Northeast / Norðausturland

East / Austurland

South / Sudurland

Q3 What is your gender?

Woman

Man

Non-binary

Prefer not to say

Q4 What is your country of birth?

(for example: Iceland, Poland, Lithuania, USA, Canada, Thailand)

Q5 What languages are spoken in your home?

(for example: Icelandic, English, Polish, Tagalog)

Q6 What is your household status?

Married or in a relationship, living with a partner

Divorced, single parent in household

Single

In a relationship but not living together 
Q7 What is your education level?

Have not finished compulsory education

Finished compulsory education

Practical studies after compulsory education

Finished upper-secondary school

Vocational / Technical college

Bachelor's

Master's or higher

Other

Q8 What is your job status during COVID-19?

I can work at home.

I have to keep working and I have to leave the house for work.

I have a job, but I am working less.

I am unemployed.

Other

Q9 How would you rate your level of understanding Icelandic? - Spoken Icelandic

Scale from Beginner, Basic, Intermediate, Advanced, Mastered

Q10 How would you rate your level of understanding Icelandic? - Written Icelandic

Scale from Beginner, Basic, Intermediate, Advanced, Mastered

Q11 How would you rate your knowledge level of COVID-19?

Scale 1 to 5 from Very poor knowledge to Very good knowledge

Q12 How well do you follow social distancing recommendations?

Scale 1 to 5 from Not at all to Very strict

Q13 What is your current status?

Living my life the same as before COVID-19.

Social distancing according to the recommendations from Icelandic authorities.

Reducing my usual activities and I am working from home.

Stay at home as much as I can; worried about getting sick or spreading the virus.

Stay at home as much as I can to protect a high-risk family member.

Stay at home as much as I can because I am in a high-risk category.

Stay at home because I am sick or have symptoms of COVID-19.

Other 
Q14 How much do you agree or disagree with the following statements?

Scale from Strongly disagree, Disagree, Neither disagreelagree, Agree, Strongly agree

The Icelandic authorities are doing a good job to prevent the spread of COVID-19.

I have been using the covid.is website to stay up-to-date.

I have difficulty getting information about COVID-19 in Iceland.

I am worried about the safety of my family or friends living abroad.

I am worried about my job security after COVID-19.

Q15 How much do you agree or disagree with the following statements?

Scale from Strongly disagree, Disagree, Neither disagreelagree, Agree, Strongly agree

I am worried about my child's health and safety while the schools are open.

I think the school has done a good job communicating with me during this time.

I agree with the way my child's school has operating since the restrictions beginning 17th March.

I think it is too soon to lift some restrictions on 4 th May.

Q16 How many children are in your household?

Q17 For those with multiple children: Please insert a single letter or nickname for each of your child (up to 5 children)

Q18 Please choose the school level of your child/children and your relationship with it/them School level of your child/children. (up to 5 children)

Pre-school

Compulsory school (1-4 bekkur)

Compulsory school (5-7 bekkur)

Compulsory school (8-10 bekkur)

Q19 Your relationship to the child/children (up to 5 children)?

Parent

Step-parent

Other

Q20 Did you keep your child home from school before the first assembly ban on 16th March? (up to 5 children)

Q21 Why or why not did you keep your child at home? (up to 5 children)

Q22 Did you keep your child home from school the week before Easter holidays? (up to 5 children)

Q23 Why or why not did you keep your child at home before Easter holidays? (up to 5 children)

Q24 Did you keep your child home from school after the Easter holidays? (up to 5 children)

Q25 Why or why not did you keep your child at home after the Easter holidays? (up to 5 children)

Q26 Did you keep your child at home after May 4th? (up to 5 children)

Q27 Why or why not did you keep your child at home after May 4th? (up to 5 children) 
Q28 What influenced your decision about your child/children going or not going to school during COVID-19? Scale from Not at all, A little bit, Quite a lot, Very much

News, articles and online information in Icelandic media

News, articles and online information from abroad

Online social media groups and discussions

Talking with family

Talking with friends

Talking with your child

If other please describe

Q29 Have you felt any pressure to keep your child in school?

Q30 What was the source of the pressure if you felt pressure to keep your child in school? Check all that apply.

Teacher or school

Family member

Friends

Wellbeing of my child

News reports

Social media

If other please describe

Q31 Have you felt any pressure to keep your child at home?

Q32 What was the source of the pressure if you felt pressure to keep your child at home? Check all that apply.

Teacher or school

Family member

Friends

Wellbeing of my child

News reports

Social media

If other please describe

Q33 How well does your child/children follow social distancing recommendations? (up to 5 children)

Q34 How could your child's school improve or help you more during COVID-19? Check all that apply according to child's school level. (up to 5 children)

More written announcements.

Translate announcements.

Phone call.

Increase school assignments 
Netla - Veftímarit um uppeldi og menntun:

Sérrit 2020 - Menntakerfi og heimili á tímum COVID-19

Decrease school assignments

Personalized support from teachers and staff.

Support from parents.

Support from a professional.

I don't need any additional help.

If other, please describe

Q35 Do you want to take part in the gift card lottery? (Leads to separate link to take part)

Elizabeth B. Lay and Brynja E. Halldórsdóttir . (2020).

"This is the first time as a foreigner that I have had such a strong connection to the state":Parents' voices on Icelandic school staying open in the time of COVID-19

Netla - Veftímarit um uppeldi og menntun: Sérrit 2020 - Menntakerfi og heimili á tímum COVID-19

Sótt af http://netla.hi.is/serrit/2020/menntakerfi_heimili_covid19/13.pdf

DOI: https://doi.org/10.24270/serritnetla.2020.18 